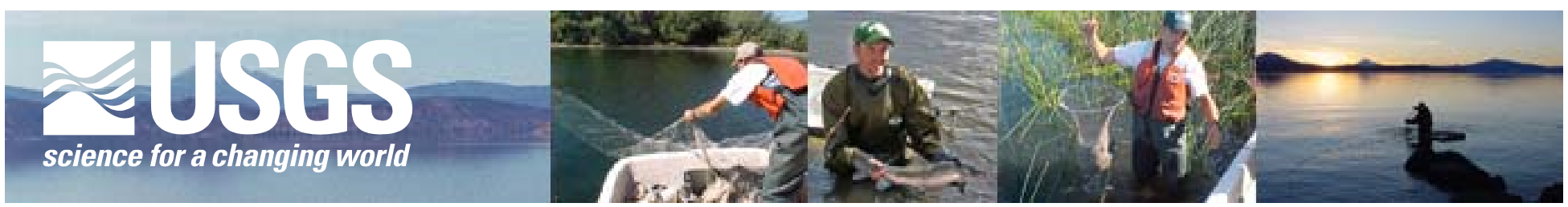

\title{
Klamath Basin: A Watershed Approach to Support Habitat Restoration, Species Recovery, and Water Resource Planning
}

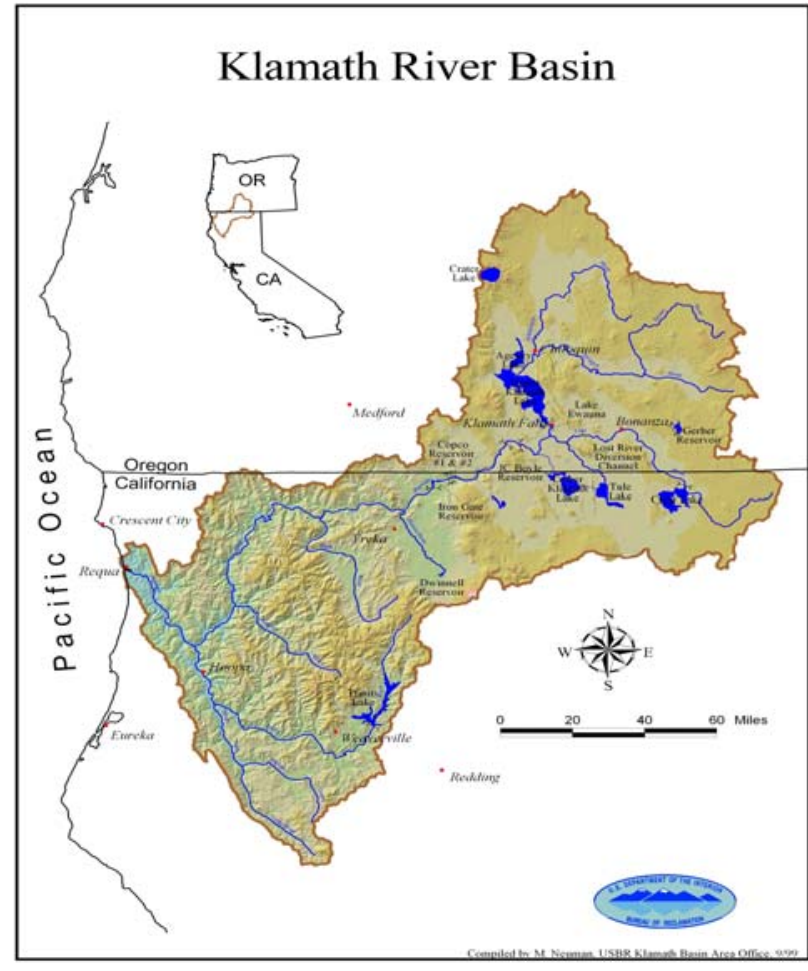

Geographic, Geologic, and Hydrologic Setting
Water allocation among human and natural resource uses in the American West is challenging. Western rivers have been largely managed for hydropower, irrigation, drinking water, and navigation. Today land and water use practices have gained importance, particularly as aging dams are faced with re-licensing requirements and provisions of the Endangered Species and Clean Water Acts. Rising demand for scarce water heightens the need for scientific research to predict consequences of management actions on habitats, human resource use, and fish and wildlife. Climate change, introduction of invasive species, or restoration of fish passage can have large, landscape-scaled consequences - research must expand to encompass the appropriate scale and by applying multiple scientific disciplines to complex ecosystem challenges improve the adaptive management framework for decisionmaking.

The Klamath River Basin embodies intense challenges and has gained national attention in federal and state resource management planning. Decreasing water availability during drought, fish dieoffs, degraded water quality, and closures of commercial salmon fisheries, all underscore the need for relevant research, improved predictive river models, and tools to evaluate the effects of alternative management actions on groundwater and river systems and their associated biota. Relicensing of dams on the Klamath River could lead to reintroduction of Pacific salmon to significant parts of their former range within the basin. An expanded USGS science agenda is responding to growing public support for watershed-scale science that addresses Klamath Basin concerns.

The Klamath River originates in southcentral Oregon, downstream of Upper Klamath Lake, and flows 263 miles to the Pacific Ocean. Upper Klamath Lake is the primary irrigation supply for the Bureau of Reclamation's Klamath Project. The Klamath Basin covers slightly more than 10 million acres, including about 6.1million acres of public land, 90,000 acres of tribal land and 3.8 million acres of private land. Iron Gate Dam is the commonly recognized dividing point between the upper and lower basins. Four additional dams that provide hydropower and irrigation water to the upper basin are located between Upper Klamath Lake and Iron Gate Dam. The upper basin is relatively dry and covers 8,060 square miles, while the lower basin is wetter and covers 7,628 square miles.
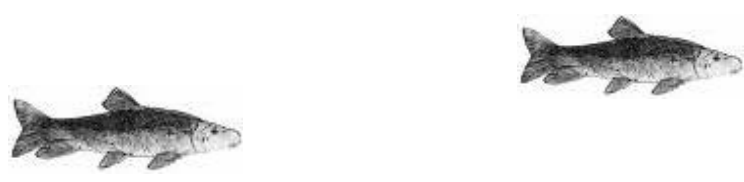

\section{Headwaters to Ocean}
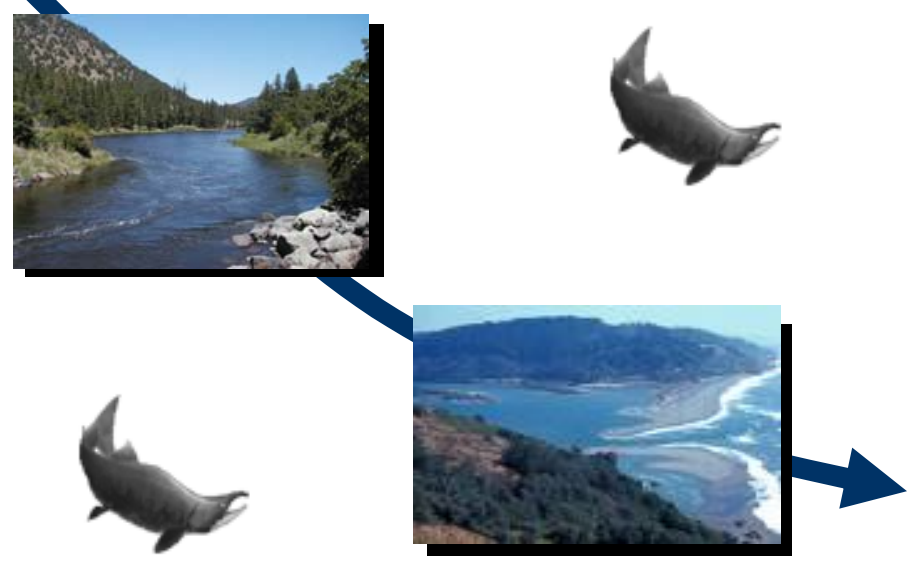


\section{A Strong Foundation of USGS Science in the Klamath Basin}

The USGS has been a major science provider to the Department of the Interior and other resource managers in the Klamath Basin since the early 1990s. Interior and tribal managers use USGS data and findings to make economically sustainable and environmentally sound natural resource decisions.

Work in the Upper Klamath Basin has focused on science to support management of water quantity, quality, and endangered Lost River and shortnose suckers. Recent USGS studies have:

- Examined aquifer hydrogeology, ground-water recharge, and the impacts of increasing ground water use;

- Improved forecasts of flows into Upper Klamath Lake to improve management of irrigation, lake levels, and downstream flows;

- Shown how water quality is influenced by lake levels, wetland management, and climate conditions; and

- Assessed the quality of stream-channel habitat to guide restoration activities.

The Lower Klamath Basin encompasses diverse waterrelated issues affecting the health and survival of salmon and other fish species. In recent years, large numbers of coho and Chinook salmon have been infected by a parasite while migrating to sea as juveniles. In 2006, the lack of returning adult salmon to the Klamath River resulted in the closure of several hundred miles of Pacific Coast salmon fisheries. These conditions served to highlight the need for an ecosystem-based understanding of stressors affecting fish in the river. The status of other fishes such as steelhead, green sturgeon, lampreys, and coastal cutthroat trout are also of high concern. The physical and biological effects of variable flow regimes in the lower river on fish distribution, abundance, and migratory behavior are critical issues being investigated by USGS.

\section{Future Science Directions}

The USGS has established research objectives to answer the critical science needs of federal, state and Tribal stakeholders in the Klamath Basin. These objectives address the impact of human activities on the changing Klamath ecosystem. Moreover, the objectives spring from research forefronts envisioned in the recent USGS publication: "Facing Tomorrow's Challenges: USGS Science in the Coming Decade." They embrace the Department of the Interior's recently released policy and publication: "Adaptive Management Technical Guide” which champions a strong and continuing linkage between science and natural resource decision-making.

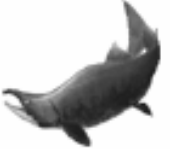

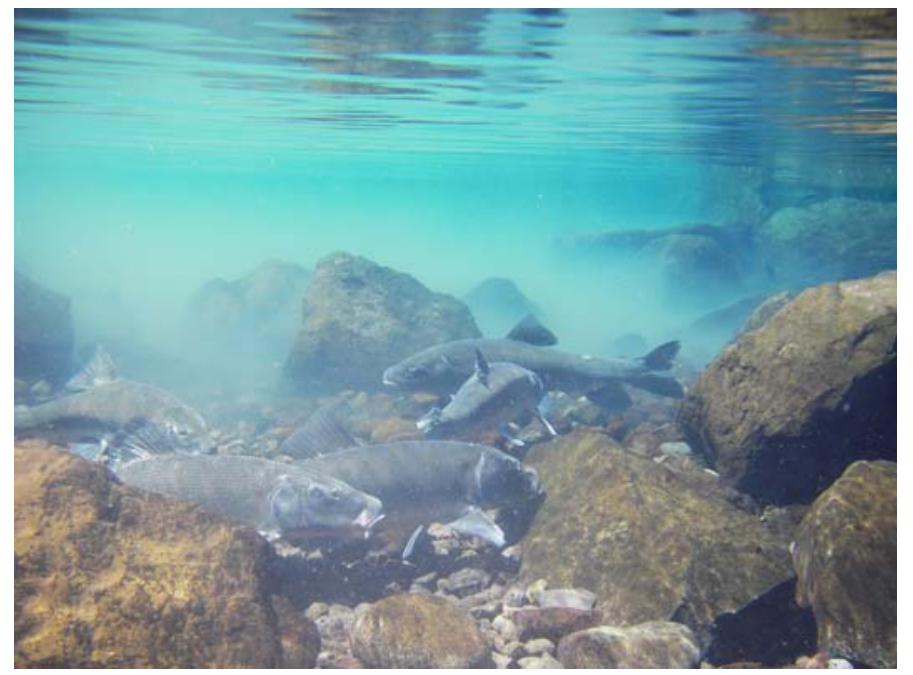

Lost River suckers spawning in nearshore areas of Upper Klamath Lake.

Recently, the USGS has engaged a diverse community of Klamath Basin stakeholders to help identify information needs and science priorities. While science priorities still address species recovery, habitat restoration, and water availability, past scientific investigations proceeded issueby-issue, and treated the Upper and Lower Klamath Basins as separate entities. Today, connections between these subbasins through biological and physical linkages —with water as the key ecological integrator-are the driving force in ecosystem scale planning. Basin-wide scaling of investigative approaches will be a critical component of future USGS research and monitoring in the Klamath Basin.

Four biological issues have emerged as high priorities within the Klamath ecosystem:

- Fish health and disease ecology

- Wetland restoration

- Riverscape ecology and predictive modeling

- Reintroduction of Pacific salmon

Supporting these biological needs are three-broad physical science priorities:

- Coupled ground-water/surface-water modeling

- Nutrient dynamics and algal processes

- Water flow and channel modeling

By addressing these priorities, the USGS will make significant contributions toward:

- Developing and evaluating restoration strategies for adaptive management;

- Predicting changes in riverine habitats and aquatic organisms in response to variable environmental conditions;

- Predicting ecosystem responses to climatic change; and

- Forecasting water availability and predicting consequences of management actions.
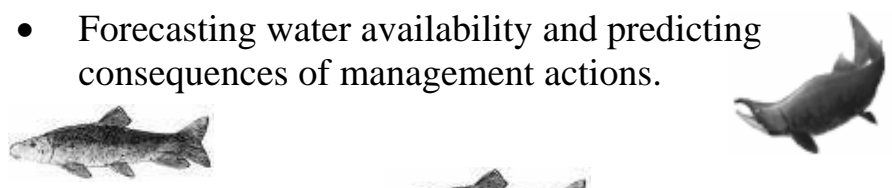


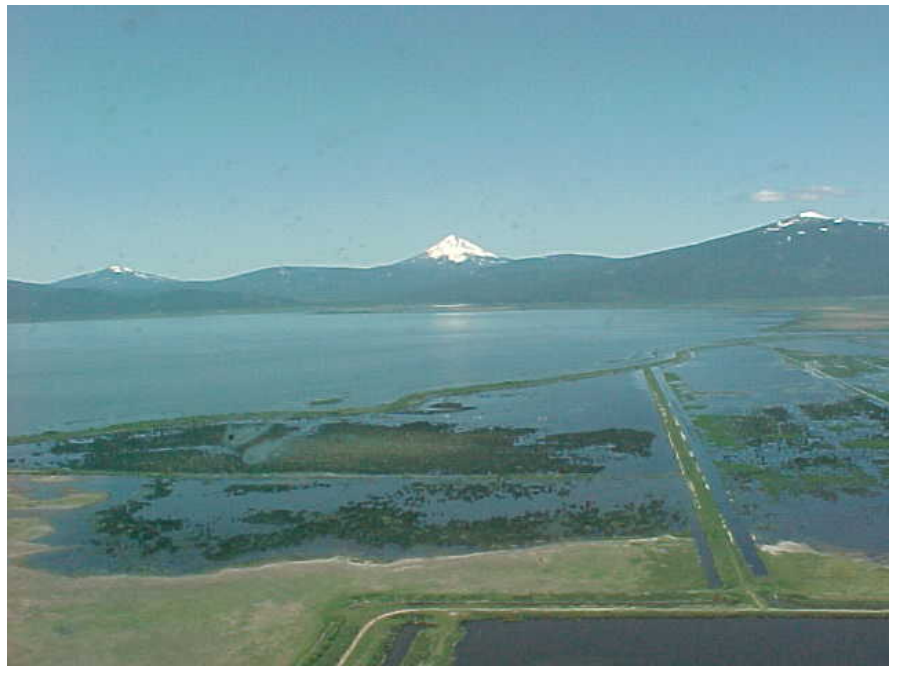

Restoration of the Williamson River Delta on Upper Klamath Lake.

USGS will address pressing science priorities, partly through a process of ecological modeling that incorporates functional linkages, ecological scaling, and large-scale external drivers such as climate change. While research on specific issues needed by resource managers will continue, future investigations will be designed to answer short-term questions that support long-term, large-scale adaptive management of the basin ecosystem.

\section{Fish Health and Disease Ecology}

Disease outbreaks have resulted in fish die-offs in both the Upper and Lower Klamath River Basins. In the Upper Basin, losses of adult shortnose and Lost River suckers have been caused by indigenous fish pathogens when the fish became stressed by poor water quality. The effects of fish condition and environmental stressors on disease resistance and survival of juvenile suckers in their first year of life are largely unknown, but could be critical to sustain the overall population. Similarly, highly visible disease-related mortalities of adult Chinook salmon in the Lower Klamath River occurred when fish were stressed by low flows and warm water temperatures. Infections seen in juvenile Chinook and other salmon are believed to be due to altered habitats. The Klamath Basin has gained national attention as a good example of how water availability, habitat conditions, and species relationships can influence the management of water for fisheries, agriculture and other human uses significant to regional and local economies.

\section{Evaluation of Wetland Restoration}

Wetland and riparian restoration in the Klamath Basin is ongoing and more is planned. Research and monitoring is needed to determine if these restoration projects improve water quality and habitat as designed. Ultimately, managers need to know if their actions increase fish production or otherwise benefit the ecosystem. For example, removal of Chiloquin Dam on the Sprague River, a major headwater tributary of Upper Klamath Lake, will require multidisciplinary scientific support to successfully restore upstream spawning habitat for the endangered suckers. Models predicting the outcome of management alternatives will enable managers to find the most effective course for restoration before implementing field projects. Ongoing scientific feedback to facilitate adaptive management among scientists and managers will allow improvement and refinement of restoration actions as they progress.

\section{Riverscape Ecology and Predictive Modeling}

The USGS River Ecosystem and Modeling Science (REMS) initiative is being designed to provide managers and the public with:

- Insight into the natural water quality and quantity variability and water transport processes;

- Up-to-date information on the impacts of human water use; and

- The capability to predict how water use, supply, and quality influence aquatic ecosystems.

State-of-the-art technologies will be employed to develop predictive models that will include decision support systems to assess the environmental consequences of alternative management strategies and will be adaptable to other large river systems.

\section{Reintroduction of Salmon}

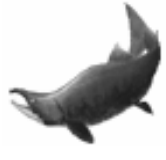

Federal Energy Regulatory Commission (FERC) relicensing of some Klamath River dams will require passage for migratory salmon that were excluded for many decades from the Upper Basin by the original dams. Re-introduction of anadromous salmon above Iron Gate Dam represents a major restoration priority to tribes, recreational and commercial fishers, and natural resource managers. Key information needs include fish passage, habitat suitability in upper basin streams, migration and seasonal rearing in Upper Klamath Lake, interactions with resident fish species, disease ecology, stock selection, and habitat conditions in the lower Klamath River.

USGS biologist displays a shortnose sucker captured at the Chiloquin Dam fish ladder (top right).

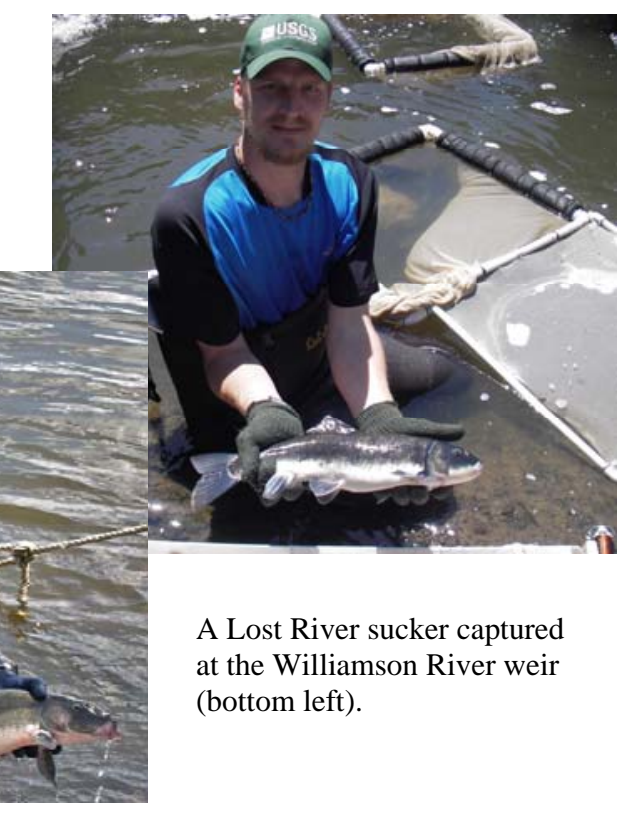




\section{Coupled Ground-Water/Surface-Water Watershed Model}

As a key USGS scientific priority, climate change will be important in western semi-arid landscapes like the Klamath Basin. A variety of data and predictive tools already exist to improve hydrologic forecasts in the Klamath Basin. The challenge will be linking these diverse models and data streams into a single tool. The USGS release of a new flow model, GS-Flow, provides the necessary framework to link these capabilities so managers and researchers can forecast hydrologic responses in the basin on temporal scales of weeks to decades. Model outputs will be linked with habitat suitability curves for endangered species and bioenergetics models of fish growth to predict multiple fish population responses to various hydrologic changes.

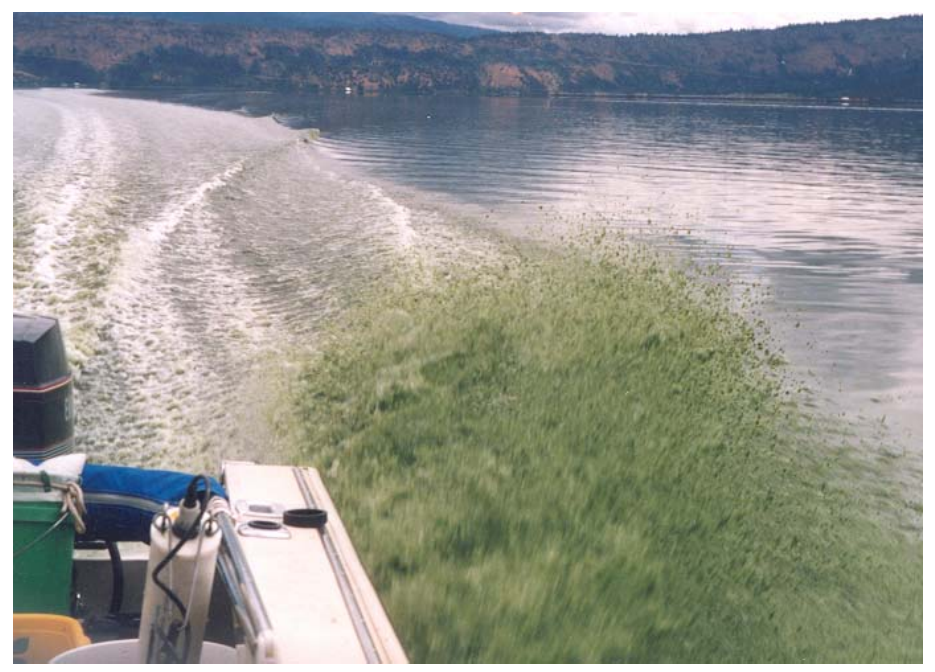

Algal bloom conditions in Upper Klamath Lake.

\section{Nutrient Dynamics and Algal Processes}

Each summer large blooms of the blue-green alga Aphanizomenon flos-aquae (AFA) in the Upper Klamath Lake, lead to low dissolved oxygen and lethal conditions for endangered suckers. Major die-offs of suckers occurred in 1986, 1995, 1996, and 1997. In order to assess the remediation strategies, which range from dredging to chemical treatments, the lake bottom will be mapped in detail to determine the nutrient forms and the degree and depth of sediment enrichment. Preliminary data indicate the presence of "hot spots" that could be targeted for remediation.

\section{Water Flow and In-Channel Modeling}

Natural cycles of flooding and sediment transport have been significantly altered in the Klamath Basin by dams and water diversion. Channel shape, bedform substrate, nutrient cycling, vegetation type, and aquatic communities have changed as a result of flow regulation. These factors in turn affect aquatic habitat suitability for key biota. The USGS will use a sophisticated hydrodynamic model of multiple geomorphologic processes in the Klamath and
Sprague rivers to predict fishery and other ecosystem responses to various management scenarios such as restoration of vegetation, augmentation of base flows, restoration of peak flows, reduction of nutrient loads, and climate change.

USGS Science to Support Natural Resource Management, Regulatory and Policy Decisions in the Klamath Basin

Habitat

- Klamath river flow/temperature/habitat modeling

- Lake level effects on sucker habitat

- Wood River wetlands restoration monitoring

Water Availability

- Ground water availability/dynamics

- Impacts of ground-water pumping on streamflows

- Withdrawals and allocation - pilot water bank performance

- Impoundments

Water Management

- Refining flow data for project management

- Flow forecasting

- Lake level

- Refuge water use

Water Quality

- Lake nutrient/algae dynamics

- Downstream impacts on Klamath River

- Water quality of inflows and river mainstem, e.g. TMDL

Dams

- FERC re-licensing, mainstem

- Chiloquin Dam investigation (planned removal 2008)

Fish Populations

- Habitat requirements and use

- Fish population responses to changes in aquatic habitat

- Sucker population indices/dynamics as indicators of habitat quality

Fish Health

- Basin integrated fish health as indicator of habitat quality

- Sucker physiological and behavioral responses to water quality
For additional information, please contact:

Frank Shipley, Ph.D.

U.S. Geological Survey

Office of the Regional Executive for Biology

909 First Ave $8^{\text {th }}$ Floor

Seattle, WA 98104

Phone: (206) 220-4600

FAX: (206 220-4624 